\title{
Integrating Environmental Education and ICT
}

\author{
Yoon-Fah Lay ${ }^{1 *}$ \\ ${ }^{1}$ Faculty of Psychology and Education, Universiti Malaysia Sabah, Sabah, MALAYSIA
}

\section{INTRODUCTION}

This Special Issue provides a platform for researchers and practitioners in environmental education with ICT to present new research findings and insights for the betterment of environmental education, nationally and internationally. Desired submissions include articles by teachers (K-12 and preschool), educators and researchers at various higher learning institutions, university professors of environmental education (EE) or Information and Communication Technology (ICT) as well as EE/Science/Mathematics educators who have successfully crafted innovative ideas for stimulating and teaching fertile minds to enhance environmental and technological literacy, promote education for sustainable living as well as global citizenship through 'Learning Science and Mathematics Together' (LeSMaT) in a borderless world. Methodological approaches and digital tools incorporated may include such as:

- project-based activities (PBA)

- problem-based learning (PBL)

- inquiry-based learning (IBL)

- constructivist and active learning strategies supported by social learning platforms (e.g., Edmodo, FB)

- e-portals, e-/d-books, digital tools

- Learning Management System (LMS)

- Content Management System (CMS)(e.g., LAMS)

\section{ARTICLE SYNOPSIS}

For quick reference, a brief synopsis of each article is provided below:

\section{A Partnership-Designed Online Module on Climate Science: Impact on Year 10 Teachers and Students}

Climate change is a layered, complex phenomenon and is contested in the public arena. For students to understand it and its likely consequences, they need to be well educated in climate science literacy i.e., be able to analyse and relate multiple sources of data and engage in arguments that are presented in the media. In this article, Wan (2019) investigated the design and impact of a school-university-industry designed online module on climate science on Year 10 teachers and their students' experiences in climate science literacy development. This paper aimed to investigate Created with 'next generation' software, the e-module allowed for personalised learning on an adaptive platform. Using a mixed-method approach, quantitative data was gathered through post-project questionnaires while qualitative data was obtained from focus group interviews, observations and open-ended questions in the survey. The findings indicate that a three-way partnership drawing on the partnership's respective expertise created learning resources that were accurate and beneficial for both students and teachers. The findings showed that teachers and students were generally positive about their experiences but more scaffolding would have benefited students and that successful teachers were those who invested time to explore and internalise the content of the e-module.

\section{Reinforcement of Scientific Literacy through Effective Argumentation on an Energy- related Environmental Issue}

In this article, Chen and Liu (2018) designed a teaching unit in a chemistry course to engage students in discussing the complex issue of renewable energy development. In the 11-week learning activities, 66 ninth-grade

(C) 2019 by the authors; licensee Modestum Ltd., UK. This article is an open access article distributed under the terms and conditions of the Creative Commons Attribution License (http://creativecommons.org/licenses/by/4.0/). 凹layyoonfah@yahoo.com.my (*Correspondence) 
students experienced individual exploration, group collaborative learning, and the operation of a web-based instant response system. Their learning outcomes were measured by the scientific conceptual test and the scientific literacy questionnaire, while their decision-making and argumentation processes were recorded using the instant response system. Results indicated statistically significant gains on the scientific concepts regarding solar cell and energy sources, as well as on the scores of scientific literacy. Likewise, students performed a substantial increase in argumentation skills, especially for those related to evidence-based arguments. Different science achievers showed a mixed pattern in proposing evidence to support their arguments. Using web technology in teaching argumentation on environmental issues is promised to raise students' interest in acquiring scientific knowledge to deal with relevant issues.

\section{Promoting Environmental Education for Primary School-aged Students Using Digital Technologies}

As demands on the environment continue to intensify, it becomes increasingly urgent to act sustainably, responsibly and respectfully, to protect and restore environments. Digital technologies, including videoconferencing, mobile apps and virtual and augmented realities, can provide new ways of engaging students in environmental stewardship. Such technologies can pique student interest, while enabling them to capture experiences of local and distal environments, to collect data and share their findings with broader audiences. In this article, Buchanan, Pressick-Kilborn, and Maher (2019) critically explores innovative, formal and informal learning practices in experiential environmental education approaches among schools, families and communities, such as citizen science projects. It draws on qualitative case study vignettes, as well as the authors' previous work and broader literature, to consider the potential and limitations of such technologies and approaches. The key question concerns how existing and emerging technologies might serve as bridges or barriers to apprenticing young people into globally-minded, environmentally responsible and respectful behaviours.

\section{Promoting Education for Sustainable Development in Teacher Education Integrating Blended Learning and Digital Tools: An Evaluation with Exemplary Cases}

In the advent of digital era, the integration of technology-enhanced teacher education has been given emphasis along with raising awareness on Sustainable Development Goals (SDG). In this article, Chin, Munip, Miyadera, Ng, and Ch'ng (2019) reported two case exemplars on the delivery of blended-mode curriculum to promote 'Education for Sustainable Development' (ESD) through training courses incorporating different strategies with the intention of providing students with more varieties of experiences related to learning science and mathematics. Facebook and Edmodo were used independently in different learning contexts. Students in the first case exemplar developed critical thinking skill as they justified their opinions in issues raised on Facebook. For hands-on experience, students planned and implemented various sustainability projects in primary schools. Students reported that the revised curriculum delivery strategies based on existing curriculum content helped to prepare them to teach sustainability in the future. In the second case exemplar, teachers were trained in mathematics digital tools for teaching mathematics and subsequently employed critical thinking when they tried to make origami paper cups with the largest possible volume. In conclusion, technology-enhanced courses on sustainability should be integrated more regularly in both pre- and in-service teacher education to reaffirm the role of teacher as a vehicle of social change in sustainable development.

\section{CONCLUSION}

It is hoped that the articles in this special issue will significantly contribute to the field of environmental education with ICT. It is also hoped that researchers and practitioners who are intrigued by environmental education with ICT will work together to resolve the lingering issues and address the emerging challenges of environmental education at both local and global levels.

\section{REFERENCES}

( ${ }^{\star}$ These are articles published in this special issue.)

*Buchanan, J., Pressick-Kilborn, K., \& Maher, D. (2019). Promoting environment education for primary school-aged students using digital technologies. Eurasia Journal of Mathematics, Science and Technology, 15(2), em1661. https:// doi.org/10.29333/ejmste/100639

*Chen, S. Y., \& Liu, S.Y. (2018). Reinforcement of scientific literacy through effective argumentation on an energyrelated environmental issue. Eurasia Journal of Mathematics, Science and Technology, 14(12), em1625. https://doi.org/10.29333/ejmste/95171 
*Chin, C. K., Munip, H., Miyadera, R., Ng, K.T., Ch'ng, Y. S., \& Promsing, N. (2019). Promoting education for Sustainable development in teacher education integrating blended learning and digital tools: An evaluation with exemplary cases. Eurasia Journal of Mathematics, Science and Technology, 15(1), em1653. https:/ / doi.org/10.29333/ejmste/99513

*Wan, N. (2019). A partnership-designed online module on climate science: Impact on year 10 teachers and students. Eurasia Journal of Mathematics, Science and Technology, 15(2), em1660. https://doi.org/10.29333/ejmste/100638

\section{http://www.ejmste.com}

